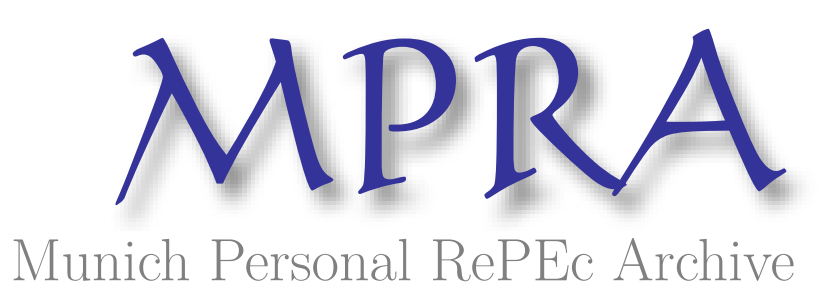

\title{
Technology and institutions: Theoretical aspects of institutional innovation and its deficiency in Haiti
}

Paul, Bénédique

CREGED - Quisqueya University

30 May 2012

Online at https://mpra.ub.uni-muenchen.de/39140/

MPRA Paper No. 39140, posted 30 May 2012 18:32 UTC 


\title{
Technology and institutions: Theoretical aspects of institutional innovation and its deficiency in Haiti ${ }^{1}$
}

\author{
Bénédique PAUL ${ }^{1}$, \\ ${ }^{1}$ Centre de Recherche en Gestion et Economie du Développement (CREGED), Quisqueya University, Haiti. \\ benedique.paul@uniq.edu.ht
}

\begin{abstract}
In the recent decades, in Haiti, a growing propensity to accept new technologies is observed. More than ever, the national market represents a potential advantage, as well as the cheapness of the labor force. Meanwhile, the country cannot take plenty advantage of its technological development potential in order to stimulate the economic growth. The paper analyzes the disadvantage factors. The conclusion show that in addition to the low level of education and the expatriation of skilled human resources, institutional characteristics may help to understand the ineffectiveness of economic development strategies implemented in Haiti in recent years. Then, we propose institutional innovation as both an analytical framework and a challenge to understand and foster economic development through technology in Haiti.
\end{abstract}

Keywords: technology, institutional innovation, institutional capital, institutional deficiency, Haiti.

JEL Classification: B52, O17, O25, L26, L52.

\section{Introduction and Purpose}

In the recent two decades, Haitians are showing their innovativeness. A growing propensity to accept new technologies and ideas is observed in the country. More than ever, the national market represents a potential advantage, as well as the cheapness of the labor force. Meanwhile, the country cannot take advantage of its technological development potential in order to stimulate the economic growth. Besides the low level of education and the expatriation of skilled human resources, it seems that institutional characteristics may help to understand the ineffectiveness of economic development strategies implemented in Haiti in recent years (Paul 2011).

These strategies are implemented by both non-governmental actors (recent development of microfinance) and the latest and actual government (repeated campaigns for foreign direct investment attraction). Neither national nor foreign investors are really motivated to finance innovation and technology uses. Only limited traditional actors like United States Agency for International Development (USAID) are supporting technology adoption in Haiti. By mobilizing findings from institutional economics, we analyze the Haitian development dilemma through weakness in institutional capital accumulation (Paul ibid.). Then, we focus on what Edinaldo Tebaldi and Bruce Elmslie (2008) called "institutional innovation". New and adapted institutions are crucial to create conditions to promote technologies and implement sustainable development strategies in Haiti. As stated by the American Association for the Advancement of Science on its report titled "Science for Haiti" (AAAS 2011), technology can help to reduce significantly Haiti's endemic poverty. But the efficiency of such a process supposes innovation in the institutional context. In this perspective, the approach initiated by Douglass Cecil North (1990) concerning the institutional change can be usefully mobilized in a search for understanding of the limitations of technology development in developing countries like Haiti. This link is consistent with Faten Loukil for whom "one cannot speak of institutional innovation without tackling the issue of driving institutional change" (Loukil 2009).

The findings of our research confirm and reinforce the usefulness of the rising literature on the relations between technology and institutions (Desierto 2005; Tremblay 2007), technology, institutions and development (Clarke 2004). The paper concludes with a pragmatic proposition of strategy and policy for Haiti. It contributes to answer the question raised by Bob Corbett: Why is Haiti so poor? (Corbett 1986).

\footnotetext{
${ }^{1}$ Article presented at the 2012 Tech4Dev International Conference on "Technologies for Sustainable Development: A Way to Reduce Poverty?" held on 29-31 May, 2012 at EPFL, Lausanne, Switzerland. See http://cooperation.epfl.ch/2012Tech4Dev.
} 


\section{Design and Methods}

The paper starts with a brief survey of the literature on institutional innovation. The survey leads us to an acceptable definition of the concept. Then we propose a new framework that can help both analysts and practitioners in Haiti. We preach by example, by mobilizing the framework in the analysis of the Haitian context in which economic development remains an insurmountable challenge. But, innovation and technology can help foster and success in development strategies, particularly in Haiti. But since technology and innovation are risky, appropriate institutions are needed to help reduce risk and encourage investment.

\section{Results}

From institutional economics to institutional innovation

Theoretical developments from institutional economics provide great and useful framework for taking in account the role institutions in economic development (Jameson 2006, Acemoglu 2003). Institutions - they can be written or unwritten (Paul ibid.) - are defined as "rules of the game" (North 1991). Rules are prescriptions that determine what is required, prohibited or permitted in an economic interactive situation (Ostrom 1984), such contextual situation is called "domain" by Aoki (2007). In business context, they allow repeatability, predictability and competitive advantages (Bresser and Millonig 2003).

From the 2000s, institutionalism won the development debate (Jameson 2006) and the $20^{\text {th }}$ century endogenous growth model is being questioned. Some authors address separately the role of institutions and technology in economic development (Rodrik and Subramanian 2003). Others test the co-evolution of these two factors in the Romer's famous economic growth (Desierto 2005). Overall, the institutional economics provides researchers a global framework to study together technology, institutions and innovations systems (Nelson and Nelson 2002). In this theoretical emerging context appeared recently the "institutional innovation" concept. It is defined by Raymond Bourdon as "axiological discovery" as well as scientific discoveries in the field of science (Bourdon 1999). More generally, for us, institutional innovation may refer to how innovatively agents create meaningful, appropriate and good institutions to regulate their interactions. It includes mechanisms used to get these institutions transformed into shared beliefs about how the game is to be played (Veblen, 1890, Aoki 2007, Hodgson 2004, 2006), and how these institutions are enforced (Grief 1993, 2006). The quality of institutional innovation may reflect the adequacy of the institutional change.

As technology and innovation are risky (Schumpeter 1934), institutions are basic in promoting economic development in developing countries. The co-evolution of technology and institutions demonstrated by Desierto (2005) is dynamic. More largely, the institutional quality affects innovation and technology (Clarke 2004). And yet, in the developing countries, like Haiti, inadequate institutions stand as obstacles to the success of development strategies. In order to reduce poverty in countries where institutional context is deficient, institutional innovation is need. In this case, we support - in the continuation of Lin (1995), Richard R. Nelson and Katerine Nelson (2002) and Tebaldi and Elmslie (2008) - that institutional innovation is a condition to development (Paul 2012). In other words, and namely in the case of poor countries, institutional innovation should precede technological innovation.

Institutional innovation is defined by Richard R. Nelson and Katerine Nelson (2002) as social innovation brought in the institutional structures needed to take advantage of the technological innovation. They consider innovative change in the institutional structures as a way to achieve adapted institutions for technological development. To their view, institutions are taken as social technologies. Then, although, "the advance of physical technologies continues to play the leading role in the process of economic growth... social technologies enter the story in terms of how they enable the implementation of physical technologies" (Nelson and Nelson, 2002).

For us, without considering institutions as a social technology, we agree with the idea that good and efficient economic institutions come from an innovative process. Our standing is consistent with Moshe Farjoun (2002) for whom "institutions (...) are continuously faced with change and innovation". They do not come from a spontaneous generation. But, following North (1991), they are humanly devised. The following framework (figure 1) provides more schematic explanations about the institutional innovation and its role in development. In this framework, we continue the actually debated theory of institutional capital. 
Figure 1. A new framework to put innovation and technology at the service of development

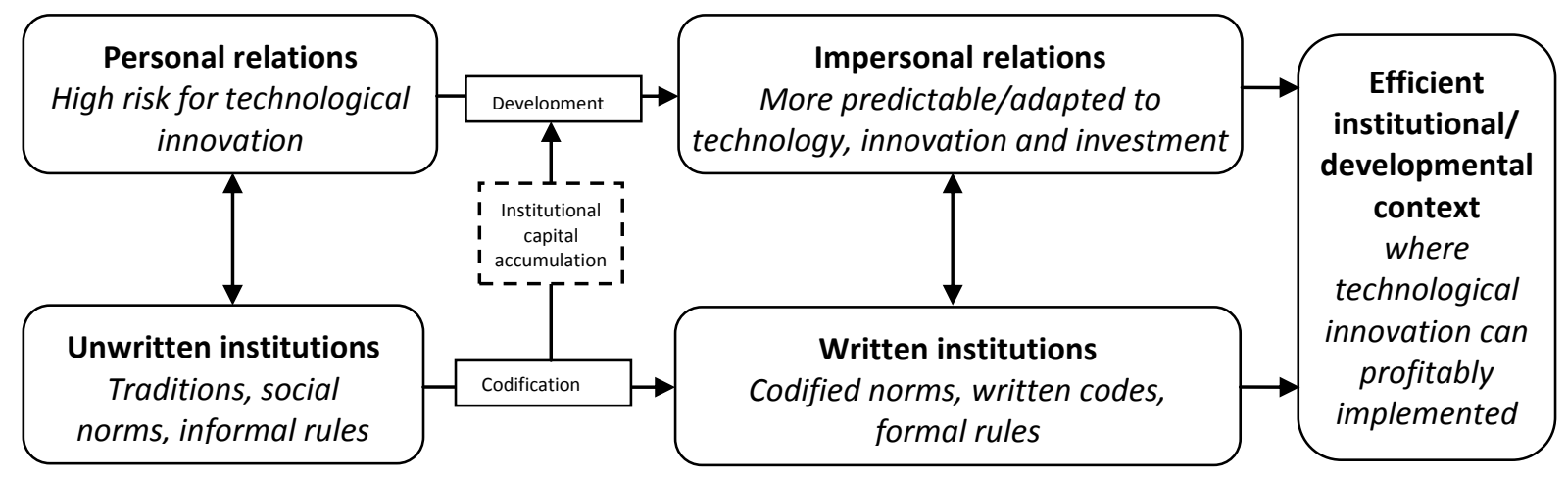

In the previous figure 1, which is consistent with Paul (2009) and Paul (2011), development is considered as a result of several capitals mobilization. In these resources named capitals, institutional capital is a fundamental one (Paul 2009). Its accumulation is provided by a progressive codification of rules that allow transformation of personal into impersonal economic relations. This transformation which implies the institutional innovation is the foundation of an appropriate developmental context where technological innovation can be profitably implemented. The next paragraph contains an attempt to apply this framework in the Haitian context.

Institutional innovation in the Haitian context

Positive co-evolution of technology and institutions is both side pulled in Haiti. In one hand, poor in Haiti are more and more innovative (open to technology and innovation), they are begging for a more competitive market. In the other hand, there is a strong dynamic for the persistence of the status quo. As poverty reduction supposes change in the socioeconomic context, namely institutional change, and institutional context is rigid and resistant to change particularly in Haiti (Paul 2011), massive technology adoption is very difficult in the country. Although, stubbornness in Haitian telecommunication market provides a successful case study in the last decade.

Since May 2006, cellular telephone was a luxury in Haiti. And it was the same for home telephone in the country. Two private companies (Haitel and comcel) were sharing the artificially limited national market, in a context of institutional weakness (Mobekk and Spyrou 2002). In May 2006, Comcel and Haitel had a total of about 500,000 subscribers; that was a cell phone coverage rate of $6 \%$ for a population of 8.2 million. Meanwhile, the public services provider, Teleco, was facing serious difficulties to be profitable.

After months of negotiations, Digicel entered the Haitian telecommunication market with a particular self-will for competition and generalized access. The results are now a particular increase in new mobile phone users and mobile phone services (call, publicity, money transfer, internet, etc.). In December 2011, Digicel alone had more than 3.5 million subscribers for a population of 10 million. This technology adoption as allowed a Mobile Money innovation implemented with the financial support of USAID and the Bill and Melinda Gates Foundation.

The USAID/Bill \& Melinda Gates Foundation's “Haiti Mobile Money Initiative” (HMMI) was launched in early June 2010 to encourage a rapid and large scale deployment of mobile money services. In the continuation of the microfinancial market growth in Haiti, the HMMI aimed to help meet the needs of Haiti's largely unbanked population. Included in a more largely project - named Haiti Integrated Financing for Value Chains and Enterprises (HIFIVE) - the HMMI kills two bird with one stone. It helps microentrepreneurs, and supports development of technologies and their diffusion in Haiti. In 2011, the two largest telephone companies, Digicel and Voila, in partnership with respectively two commercial banks (Scotia Bank and Unibank) operating in Haiti presented "Tchotcho Mobile" and "T-cash". Now, even informal and rural entrepreneurs in Haiti are using these mobile financial solutions. But first of all, institutional innovation in the telecommunication market was required before this successful experience in technological innovation. The same institutional innovation managed by the National Committee of the Telecommunications (CONATEL, in French) opened modernization in the public Teleco and entry for international investors in the telecommunication market. At the end of the year 2011, the market has become more and more competitive, with the entry of the Natcom (officially September 7, 2011).

Natcom (contraction of National Communication S.A.) is a leading telecommunication operator with the share of the Haitian national telecommunication company (TELECO) and Viettel Group (the state-owned company of Vietnam). Viettel Group has invested 100 million U.S. dollars to install the optical fiber cables all over the 
country (more than 3000 kilometers). It is the only cable infrastructure in Haiti, enabling fix, internet and mobile services. Natcom hopes to have about 2 million subscribers at the end of 2012. According to that numbers, more than $50 \%$ of the population is using mobile phone, and mobile services and technology are no longer a luxury.

After the exposition of the telecommunication example of institutional innovation in Haiti, it is necessary to relativize our explanation. Because, in its national dimension, the institutional context remains deficient. Three main sectors can help us consider this deficiency: land, contracts and justice. They can be taken as three key institutional innovations to be operated in Haiti.

Land tenure and land property rights are under-defined and under-protected. Although Land is being less and less problematic in Haiti (Lundahl 1991), in the rural Haiti, peasants and farmers have a limited formal access to land. Many of them are using land under informal tenant farmer contracts. In the urban Haiti, there is a critical absence of cadastre. This institutional lack, in addition to the inadequate legal framework for notary, leads many Haitians to pay several times for the land. Finally, this limitation in the Haitian institutional development may be accountable of Haitian poverty. This poverty is statistically worst in the rural Haiti (Dupuy 1989, Lundahl 1991, Sletten and Egset 2004, Paul 2011).

Contracts are crystallization of institutions. But they need to be reinforced by national legal framework, notably in the private sector. When business relations between economic agents are not sufficiently protected by clear legal institutional framework, it is almost impossible, even unserious or naïve, to claim national investment mobilization. This is also a signal for international investors. As argued more largely by others, the national institutional profile is determinant in entrepreneurship unlocking and Foreign Direct Investment (FDI) attraction (Kostova 1997, Busenitz et al. 2000, Berthelier et al. 2004, Bénassy-Quéré et al. 2005).

Justice can be analyzed either at individual behavior or national system. Suppose FDI are sensitive to justice behavior and system, Haiti has a big problem to be considered as a destination for foreign investment. Foreign investors need to have guarantee for adapted justice decision when private contracts they can sign are un-obeyed. In the case of Haiti, where what we can call "corruptogenetic" individual behavior is not sufficiently sanctioned and national juridical system is not able to punish crimes, a deep-rooted institutional innovation is need before starting development through technology, innovation and investment. It may be the same for several developing countries.

\section{Conclusions}

In this paper, we aimed to show how institutional economics can help to explain the link between technology and institutions. The paper provides a framework on institutional innovation that should be used in Haiti - and in similar poor countries - in order to put innovation and technology in the service of development strategies.

In Haiti - as argued by Acemoglu, Johnson and Robinson (2000) and Acemoglu and Robinson (2008) for similar developing countries - new adapted institutions are needed to break the persistence of the status quo, and support technology improvement. For this reason, recent attempt for institutional changes, such as Decree on co-property rights in Housing, expressed good will of the Ministry of Trade and Industry (MTI) to register little business in a national database, can be applauded. But, more creative and adaptive institutional innovation is needed to overcome path-dependency and inertia that process of institutional change is facing in the country.

As we know that the Haitian economy is now dominated by informal tertiary sector (Paul et al. 2010), new institutional framework is needed to go with the evolution of the national trend of the economy. Because economic development leans upon formal and impersonal relations (Paul 2011), institutional innovation deficiency appears as a handicap to be addressed first in the context of implementation of development strategies. More largely, institutional development appears as a good way to foster economic development through technology in Haiti and other poor countries. The improvement of Haiti's institutional profile supposes more efforts for efficient institutional innovation. And practitioners need to be animated by voluntarism because of elite's fighting for persistence of the status quo (Acemoglu and Robinson 2000, Farjoun 2002). Haiti's social structure - largely debated by George Eaton Simpson (1941) - is still marked by past institutions.

\section{References}

Acemoglu, D (2003). Root Causes. A historical approach to assessing the role of institutions in economic development. Finance \& Development, 40(2), 27-30. 
Acemoglu, D., Johnson, S., Robinson, J. A. (2001). The Colonial Origins of Comparative Development: An Empirical Investigation. American Economic Review, 91(5), 1369-1401.

Acemoglu, D., Robinson, J. A. (2000). Political Losers as a Barrier to Economic Development. American Economic Review, 90, 126-44.

Acemoglu, D., Robinson, J. A. (2008). The Persistence and Change of Institutions in the Americas. Southern Economic Journal, 75(2), 282-299.

Aoki, M. (2007). Endogenizing institutions and institutional changes. Journal of Institutional Economics, 3(1), $1-31$.

Bénassy-Quéré, A., Coupet, M., Mayer, T. (2005). Institutional Determinants of Foreign Direct Investment. Centre d'Etudes Prospectives et d'Informations Internationales (CEPII), Working Paper, 2005-05 Berthelier, P., Boudon, R. (1999). Le sens des valeurs. Paris: PUF.

Desdoigts, A., Ould Aoudia, J. (2004). Profils Institutionnels : Une base de données sur les caractéristiques institutionnelles de pays en développement, en transition et développés, Revue Française d'Economie, 19(1), 121-196.

Busenitz, L. W., Gómez, C. and Spencer, J. W. (2000). Country Institutional Profiles: Unlocking Entrepreneurial Phenomena. Academy of Management Journal, 43(5), 994-1003.

Clarke, G. R. G (2004). How the Quality of Institutions Affects Technological Deepening in Developing Countries. World Bank Development, Resource Group.

Corbett, B. (1986). Why Haiti Is So Poor? St Louis (USA): People to People Inc. The Haiti Project Newsletter.

Desierto, D. (2005). The Co-evolution of Institutions and Technology. Working Paper, CWPE, 0558.

Dupuy, A. (1989). Haiti in the World Economy. Class, Race, and Underdevelopment, since 1700. Boulder, Co and London: Westview Press.

Farjoun, M. (2002). The Dialectics of Institutional Development in Emerging and Turbulent Fields: The History of Pricing Conventions in the On-Line Database Industry. The Academy of Management Journal, 45(5), 848874.

Greif, A. (2006). Institutions and the Path to the Modern Economy: Lessons from Medieval Trade. New York: Cambridge University Press.

Greif, A. (1993). Contract Enforceability and Economic Institutions in Early Trade: The Maghribi Traders' Coalition, American Economic Review, 83, 525-548.

Hodgson, G. M. (2006). What are institutions? Journal of Economic Issues, 40(1), 1-25.

Hodgson, G. M. (2004). The Complex Evolution of a Simple Traffic Convention: The Functions and Implications of Habit, Journal of Economic Behavior and Organization, 54(1), 19-47.

Kostova, T. (1997). Country institutional profiles: Concept and measurement. Academy of Management Best Paper Proceedings, 180-189.

Lin, J. Y. (1995). Endowments, Technology, and Factor Markets: A Natural Experiment of Induced Institutional Innovation from China's Rural Reform. American Journal of Agricultural Economics, 77(2), 231-242.

Loukil, F. (2009). Normalisation et développement durable. Innovations, 29, 35-57.

Lundahl, M. (1991). Underdevelopment in Haiti: Some Recent Contributions. Journal of Latin American Studies, 23(2), 411-429.

Mobekk, E., Spyrou, I. S. (2002). Re-evaluating IMF involvement in low-income countries: the case of Haiti. International Journal of Social Economics, 29(7/8), 527-537.

Nelson, R. R., Nelson, K. (2002). Technology, institutions, and innovation systems. Research Policy, 31, 265272.

North, D. C. (1991). Institutions. Journal of Economic Perspectives, 5(1), 97-112.

North, D. C. (1990). Institutions, Institutional Change and Economic Performance. Cambridge: Cambridge University Press.

Paul, B. (2012). Le changement institutionnel en Haïti, les véritables enjeux. Recherche Etudes et Développement, 5(1), fourthcoming.

Paul, B. (2011). Institutional Capital in the Analysis of Economic and Social Change: An Empirical Study in the Haitian Microfinance Sector. PhD dissertation in Economics. Montpellier 1 University in joint supervision with Haiti State University.

Paul, B. (2009). Reclaiming Institutions as a Form of Capital. Proceedings of the Pennsylvania Economic Association 2009 Conference, 137-148.

Paul, B., Daméus, A., Garrabé, M. (2010). Le processus de tertiarisation de l'économie haïtienne. Études caribéennes, 19, online since 20 mai 2011. http://etudescaribeennes.revues.org/4728. Accessed 26 February 2012.

Rodrik, D., Subramanian, A. (2003). The Primacy of Institutions (and what this does and does not mean), Finance \& Development, 33(3), 31-34.

Schumpeter, J. A. (1934). The Theory of Economic Development. Cambridge, MA: Harvard University Press. Simpson, G. E. (1941). Haiti's Social Structure. American Sociological Review, 6(5), 640-649. 
Sletten, P., Egset, W. (2004). Poverty in Haiti. Oslo: FAFO Paper, 31.

Tebaldi, E., Elmslie, B. (2008). Institutions, Innovation and Economic Growth. Journal of economic development, 33(2), 27-53.

Tremblay, D.-G. (2007). Le rôle des institutions dans le processus de l'innovation ; l'apport de Thorstein Veblen. Revue Interventions économiques, 36. Online since $01 \quad$ October 2007. http://interventionseconomiques.revues.org/562. Accessed 07 February 2012.

Veblen, T. (1899). The Theory of the Leisure Class: An Economic Study of Institutions, New York: MacMillan. 